\title{
Study on Historical Conditions vs. Mathematics Testing Performance of Students in Romania between 1980 - 2011
}

\author{
Radu Nicolescu \\ University of Oklahoma
}

\begin{abstract}
This is an overview of the Romanian past and present education system between 1980 and 2011. Romania has gone through a period of changes over the last three decades, and consequently the education system suffered modifications. Traditional methods were replaced gradually by modern approaches, although the general structures are similar. The expected result was an increase in the TIMSS scores. In reality, once the reforms have been initiated, a downtrend in scores was noticed. While there were no available studies showing why the downtrend occurred or what factors may be responsible, one may suggest that an education reform of such proportions may have unintended consequences especially on short term, and, eventually, the intended achievement can differ from the real achievement. Certain factors, such as student accountability, the new media, the impact of the market economy, or political turmoil can also influence students, parents, and teachers and alter the educational process.
\end{abstract}

\section{Introduction}

Most countries in Eastern Europe are experiencing a transition from the traditional education system employed by the former communist regime to a newer system, characteristic to the Western type of education. In particular, Romania has gone through a period of many changes moving from the communist era to the market economy and globalization in the last three decades, and, as a consequence, the education system suffered modifications as well.

The purpose of this article is to describe characteristics of the Eastern Europe education system, focusing on Romanian curriculum, and to present the unintended consequences following supposedly positive changes in the Romanian curriculum after 1990. The topic was suggested after certain differences were noticed between the Western way of teaching including the curriculum design, and its Romanian counterpart, the latter being driven by a more traditional approach. Since most countries in Easter Europe are experiencing a transition from the old traditional education system employed by the former communist regime to a newer system characteristic of the Western type of education, this paper will outline both aspects for comparison. From this point of view there are big differences between the decade before 1990 and the following two decades. Various influences such as teachers' approaches, decreased student accountability, and parents' unpreparedness for new teaching methods, may have led to lower scores in the international mathematics tests from 1996 to 2007. Although the results for year 1996 are also compared with those of year 2007, the present paper does not intend to imply correlations or cause-effect relationships between pre and post-transition systems and performance.

There are two aspects that deserve to be discussed, about this study. First, while the reforms in education seemed positive, the TIMSS scores did not show improvement, or even more, they decreased for the last decade. Second, a different approach shows that the students' scores on the International Mathematics Olympiads were as high as they used to be before the reforms were initiated.

\section{Romanian Education System}

During the communist regime that ended in December 1989, Romania, as well as all other countries in the Eastern Block, based their education system on several goals dictated by government priorities. A top priority was to keep the country strong economically, able to compete successfully especially in technology. [3] The result was similar to a national standardization in education. When a similar situation happened in the United States, there were voices discussing the effectiveness of this strategy: "The aim of keeping our economy strong seems reasonable, but the demands of accountability and standards at such a time seem oddly out of place" [5]. 


\subsection{The Decade 1980 - 1990}

In Romania, public schools did not charge for tuition during the 1980s, and free tuition is still offered in the public system. The typical length of study used to be four years of elementary education (grades 1-4), four years of middle school (grades 5-8) and four years of high school (grades 9-12). The admission to high school was based on one criterion the individual results on the Admission Tests, organized by the Ministry of Romanian Education at the end of the $8^{\text {th }}$ grade, and administered by each High School to all candidates for that particular High School.

Each of the school grades 9-12 still had its own individual curriculum, nationally established by the Ministry of Education, unique when compared with any of the other grades' curriculum. Some differences existed before as well as after 1990 in respect to vocational profiles of certain high schools (arts, Romanian literature, foreign languages, etc). A typical high school curriculum, for example, was based on 12 to 14 subjects per year of study, as follows: Romanian Literature, History, 2 Foreign Languages (generally, the two languages were chosen from English, French, German, Italian, Spanish and Russian), Religion (only after 1990), Mathematics, Physics, Chemistry, Biology, Geography and Physical Education, plus a number of elective courses. The credit hours system was not used, and one failing subject was reason for failing the whole year, in which case all classes were taken again, even those passed with high grades. A typical distribution of weekly number of hours per $1^{\text {st }}-8^{\text {th }}$ grades and subjects can be seen in Table 4 .

Usually, classes had between 30 and 40 students who began together in the first grade and advanced together (except those who would fail one year or another) through all of the first eight grades. The system worked similarly for those who passed the high school entrance exam and began together in the ninth grade advancing through the rest of the high school grades. During a typical school day the students stayed in the same classroom the same for the whole year, except labs - biology, physics, chemistry, while teachers switched places. Typically there were 4to 6 back-to-back classes a day. Although one class period lasted 50 minutes, usually some core subjects like mathematics, physics or literature were taught in a series of two 50 minutes periods.

High achieving Romanian students were not given the option of skipping grades, and there were no Advanced Placement or Honor courses. There was a mentor assigned to a whole grade, and they used to meet once a week, discussing general issues related to grades, attendance or ethical problems. Strong discipline and traditional education methods were employed, and still were a characteristic of the next decade of transition, 1990 - 2000, when student accountability was very high. During a typical mathematics class period, the teacher lectured about the subject to be discussed, accepting students involvement in discussions, although this was limited. After, or during the lecture, students could ask questions or suggest implications of the concepts presented by the teacher. Eventually students were asked to come randomly to the blackboard and solve problems related to the subject discussed by the teacher. This method had two purposes: first, it led to good class practice and ensured a better understanding of the concepts discussed, and second, encouraged students to pay attention during teacher's lecture. There were no grades assigned to students based on these answers, but the teacher could asses better the way students understood the lesson and were able to solve applications. Other teachers preferred to do the applications part themselves rather than asking students to do that - a method largely used at college level today.

\subsection{The Following Two Decades}

Many characteristics that existed before 1990 in the Romanian educational system continued to persist in the following decades. Traditionally, the most common conception about teaching and assessing the overall results was that the level of national education can be inferred by analyzing the results of very welltrained groups of students in the international competitions where Romania participated. Although this seemed to justify government expectations during the few decades after the WWII, when the Cold War came to an end after 1990s, it was discovered that unfortunately, the performance of students in the educational system as a whole was at a significantly lower level.

When performances of samples of students were examined after international competitions during the last decade, it was discovered that although Romania scored very low overall which was consistent with the downward trend for the previous 5 years there were notable discrepancies in students' abilities. For example, one of the areas of study - solving theoretical problems showed that the Romanian team scored well above the international mean. The explanation for such findings resides in the types of problems used by math teachers in class. There are two major areas where math teachers still insist on demonstrating in their teaching after 1990 - a spirit of competition, and a high level of abstraction. [7] Just a few words about each of these areas will help 
the reader better understand some of the approaches used by teachers. Being rewarded for training gifted students and for leading winning mathematics teams in local, national or international competitions, teachers became involved more often in these activities, but focused especially on children who were potentially able to achieve such goals. Of course, the negative consequence of this spirit of competition was the neglect of the vast majority of children without outstanding performances in mathematics.

Developing a high level of abstraction was another issue that did not favor the students although they were required to improve in this area. Despite the fact that most problems solved in class were closed or almost closed, the few open ended problems had high degrees of difficulty, and many were solved based on learned solutions techniques.

\subsection{Structure of the Present Education System}

Due to various changes in the politics and leadership in Romania, the structure of the education system suffered multiple modifications during the last two decades. Although it is impossible to predict a certain valid model for a long period of time, a general description can be found below.

Today, in accordance with Education Act, the public education system in Romania includes:

- Pre-school education (aged 3-7 - lower, middle, upper, and groups), in kindergartens

- Primary education (compulsory) grades 1-4.

- Lower secondary education (gymnasiums compulsory) grades 5-8 - it ends up with the taking of a "national evaluation examination" on mathematics and maternal language (the language in which the student studied in school - it can be Romanian, Hungarian or German). The average grade from the National Evaluation exam is one of the criteria for being admitted in a public high school, where tuition if free. Public high schools represent the overwhelming majority of all high schools in Romania. The admission in such a high school, in the $9^{\text {th }}$ grade is based on the admission score, calculated as the average between the average grade on the National Evaluation and the GPA from the previous years from $5^{\text {th }}$ to $8^{\text {th }}$ grade. The results for 2011 at the National Evaluation examination for Romanian language and mathematics can be seen in Table1 and Table 2, respectively.

- Higher secondary education (high school education) refers to grades 9-12. During the last decade 2000-2010 several other methods, different from the previous decades were introduced for the admission in high school process, including the most popular criteria - a cumulative ranking based on a weighted average between the National Test scores and the GPA for the previous 4 years, correlated with an individual option for a particular high school.

.High school education has the following branches: 1. Theoretical (or college preparatory); 2. Technological; 3. Vocational. Enrollment in high school is based on the National Evaluation results cumulated with the GPS of the previous four years from the $5^{\text {th }}$ to the $8^{\text {th }}$ grade. High school studies end up with a "baccalaureate examination". After passing this examination, the graduates get the "baccalaureate diploma". Only those students who passed the baccalaureate exam and obtained their diploma are allowed to participate at the college admission exam. The baccalaureate examination is controversial nowadays in Romania, where in 2011 only approximately $50 \%$ of the candidates (about 100,000 of 200,000 students) passed.

- Vocational education (1, 2, or 3 years)"vocational schools" and apprentice schools. Lower secondary education graduates regardless of their National Evaluation score, can enroll in the "vocational schools' and in the apprentice schools. Admission is granted on the basis of predominantly practical tests, specific to the selected profession

- Post-high school education (1-3 years), organized in post-high school and foreman schools specializing the students in domains required by various companies or institutions. Admission is granted on a competitive basis

The typical structure of the Romanian education system is shown in Table 3.

\subsection{Curriculum Principle}

After 1990 efforts were made to align the Romanian education system to the Western trend, and to adopt a series of principles and practices targeting future success in teaching and learning. In order to better describe such measures, a set of principles defining curriculum are presented next.

The present curriculum framework, published in 1998 [6], defines the principles of learning, teaching, and assessment, similarly to those used by NCTM:

\section{Learning Principle states that:}

- Students learn in different ways and rhythms.

- Learning presupposes continuous investigations, effort and self-discipline.

- Learning develops attitudes and skills and contributes to the acquisition of knowledge.

- Learning must start from relevant aspects for the personal development of the student and for inclusion in social life 
- Learning can be carried out through self-study and group activities.

Teaching Principle states that:

- Teaching must generate and stimulate the students' motivation for permanent learning.

- The teachers and primary school teachers must create various learning opportunities that should facilitate the intended achievement of goals.

- The teachers and primary school teachers must discover and stimulate the students' interests and skills.

- Teaching does not only mean transmitting knowledge, but conveying moral, behavioral and attitudinal values as well.

- Teaching must facilitate the transmission of information and skills from one domain of study to another.

- Teaching must be carried out in context relating school activity to everyday life.

Assessment Principle states that:

- Assessment is an essential dimension of the curricular process and an actual classroom activity.

- Assessment must combine the use of a wide variety of methods

- Assessment must be a regulating process that informs the educational agents about the quality of school activity.

- Assessment must lead the students to a correct selfevaluation and a continuous improvement of their performance

- Assessment is based on curricular performance standards, oriented towards the abilities of the student at the end of his/her educational years when he/she is to enter social life.

Starting with the promotion of students who are in the fifth grade in the 1999-2000 school year, the transition is made to the nine years compulsory education (grades 1-9, in accordance withAct151/July/30 1999). Curricular areas were: Languages and Communication, Mathematics and Natural Sciences, Man and Society, Arts, Sport and Physical Education, Technologies, Counseling and Orientation.

The framework for study planning - grade 1 through 8 is presented in the table on Table 3:

\section{Discussion of trends in international mathematics and science study (TIMSS)}

There was no available data regarding performance of Romanian students for internationally accredited tests, during the first decade of this study $(1980-1990)$. As it was already mentioned, the only estimates were based on the results of highly prepared mathematic teams participating in International Olympiads. The International Mathematical Olympiad (IMO) is a high school mathematics competition in which during a two-day period participants are required to solve six problems covering highly difficult pre-collegiate mathematics. The competitors are selected from the best high school math students of each participant country, and each team is prepared by teachers specially trained for this competition. The first IMO took place in 1959, in Romania. Since then, it was held annually with the exception of 1980 in countries all over the world, and Romania excelled between 1978 and 1987, when, competing against top teams from countries with great potential, such as China, former USSR, USA or Japan, managed to place first three times (1978, 1985, and 1987). Unfortunately this gives a false impression about the overall level of preparedness in mathematics before year 1990.

During the second and third decades Romania started to participate in international assessments and comparisons like TIMSS became possible. The Trends in International Mathematics and Science Study (TIMSS) is a "comparison in mathematics and science achievement carried out since 1995 by the International Association for the Evaluation of Educational Achievement (IEA), an international organization of national research institutions and governmental research agencies." Data were collected every four years, since 1995 until 2007, for $4^{\text {th }}$ and $8^{\text {th }}$ graders, and the Romanian Department of Education and Research reported scores for the years 1999, 2003, and 2007, after the affiliation to this organization, in 1996. Low scores, shown in the following table, prompted researchers to look for reasons that caused this underperformance.

In Figure 1 Romanian students' scores are shown, as well as the first three places (Singapore, Chinese Taipei and Japan), and the last - Ghana. Romania placed on the $28^{\text {th }}$ position, surpassing 20 other countries. One fact seems to be obvious: while the results in the IMO continued to be situated at a high level, the overall scores obtained by Romanian students in the TIMSS decreased. [4] 


\begin{tabular}{|c|c|c|c|c|c|c|c|}
\hline & & \multicolumn{5}{|c|}{ Cognitive Domain } \\
\hline Country & Avg. & Biology & Chemistry & Physics & Knowing & Applying & Reasoning \\
\hline TIMSS & 500 & 500 & 500 & 500 & 500 & 500 & 500 \\
scale avg. & & & & & & & 564 \\
\hline Singapore & 567 & 564 & 560 & 575 & 567 & 554 & 541 \\
\hline Chinese & 557 & 549 & 573 & 554 & 560 & 565 & 560 \\
\hline Taipei & & & & & & 554 & 534 \\
\hline Japan & 554 & 553 & 551 & 558 & 555 & \\
\hline$\ldots$ & & & & & & & \\
\hline Romania & 462 & 459 & 463 & 458 & 470 & 451 & 460 \\
\hline
\end{tabular}

Figure 1. The Romanian position in TIMSS 2007 testing

In "Comparative Study on Romanian School Science Curricula and the Curriculum of TIMSS 2007 Testing," Liliana Ciascai conducts an analysis based on Bloom's taxonomy for cognitive domain, and identifies not only the common points of Romanian and TIMSS curricula, but also "the system of competencies necessary to be developed for Romanian students in order to increase their results in international testing." [1] A description of the analysis process is beyond the purpose of this article, but the results showed that "The difference between the numbers of competencies involves by TIMSS 2007 and the number of competencies developed to students of 8th grade can be a cause of poor performance of the Romanian students testing" [1] and recommends an adjustment of the Romanian science curriculum with TIMSS curriculum.

\section{Conclusion}

High discipline and traditional teaching methods in general were the characteristics of the Romanian education system until the fall of the communism in Eastern Europe during late ' $80 \mathrm{~s}$ and early '90s. Presently, the Romanian education reform is going through a process of modernization and is aligning to the global trends according to which opposite tendencies (centralization vs. decentralization, global vs. traditional or local curriculum or creativity vs. performance) still compete. The effects of these transformations are expected to occur soon at all school levels: less emphasis on memorizing rules and computing in comparison with problem solving activities, involvement in practical context, and search for solutions beyond the given frame of school knowledge. [6] One of the most important changes in respect to teaching and educators' behavior is the attitude of the teacher, who is expected to switch from being an information provider to becoming a facilitator of learning, while students will learn to cooperate in teams and self-construct knowledge, rather than being passive receivers of information and working alone. For the Romanian education system, this is an important step in understanding the curriculum as "an interrelated set of plans and experiences that a student undertakes under the guidance of school", and therefore, the enacted curricula will consist of an "amalgam of planned and unplanned activities" [2].

Although the measures mentioned above seem to define a positive input, the scores in the latest TIMSS examinations suggest otherwise. Is the downtrend showing that a wrong approach is used? What are the factors that could have influenced in a negative way the scores in the international tests? Were the Romanians correct in estimating the overall students' preparedness after the breakthrough on 1959? What 
was the difference between the average students and the top ones, competitors in IMO contests?

Some of the answers to these questions have been suggested since long time ago. After 1990 it was obvious that more freedom brought more human rights and consequently more student freedom, which is associated with less discipline and less student accountability. This might be one of the factors that differed significantly from the 1980 - 1990 decade. Another factor may be linked to the new type of society. Once the market economy was implemented, there was significantly less control in respect to the values promoted by the mass media. New television channels had huge incentives for presenting financial success as the top priority of our society. Children or young students rarely see a connection between success and education, and, as a result, they will look for a shortcut for future successful financial achievements. Finally, another factor may be linked to the political turmoil in Romania after 1990. Several political parties claimed power over the last two decades, and policies in education changed very often. The curriculum was also changed almost every year, and many students as well as parents and teachers were disoriented by new reforms. In these conditions lower performance was a logical outcome.

More research is necessary to determine the impact of each of the three factors mentioned above on the weak results of Romanian students in the last few TIMSS tests. The main challenge of such studies would be the low number of TIMSS reported scores and the lack of such data before 1990. Also, while discipline and misguidance can provoke a fast drop in performance, as a general rule, educational reforms should not be expected to deliver appropriate results after short periods of time.

\section{References}

[1] Ciascai, L., (2009). Comparative Study on Romanian School Science Curricula and the Curriculum of TIMSS 2007 Testing. Acta Didactica Napocensia, Vol. 2 (2), pg. 25 - 34.

[2] Marsh, J. M., Willis, G,. (2010). Curriculum. Alternative Approaches, Ongoing Issues.

[3] Ministry of Education and Research of Romania (2001). The Romanian Education System.

[4] The National Report. UNESCO, March 2001.

[5] Noddings, N., (2007). The Aims of Education. In Flinders, D. J., Thornton, M. S., (Ed.) The
Curriculum Studies Reader (p. 431). New York and London: Routgedge.

[6] Romanian National Curriculum. Retrieved from http://www.curriculum2008.edu.ro/Ciclul_secundar_ superior/Liceu/Matematica_si_stiinte on 03/22/2012.

[7] Singer, M. F. (2007). Intercultural Aspects of Creativity in a Global World. Retrieved from http://construct.haifa.ac.il/ rozal/templeton/Florence $\% 20$ Mihaela\%20Singer-

\%20templeton\%20workshop.pdf on 03/22/2012. 


\section{Appendix}

Table 1. National evaluation 2011 "Romanian language and literature" Number of students vs. grades

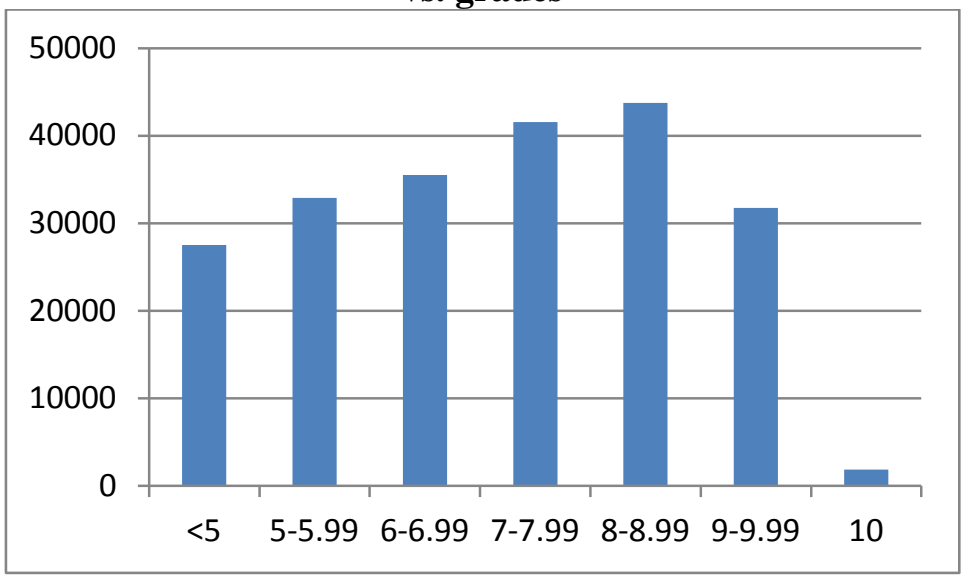

Table 2. National evaluation 2011 "Mathematics". Number of students vs. grades

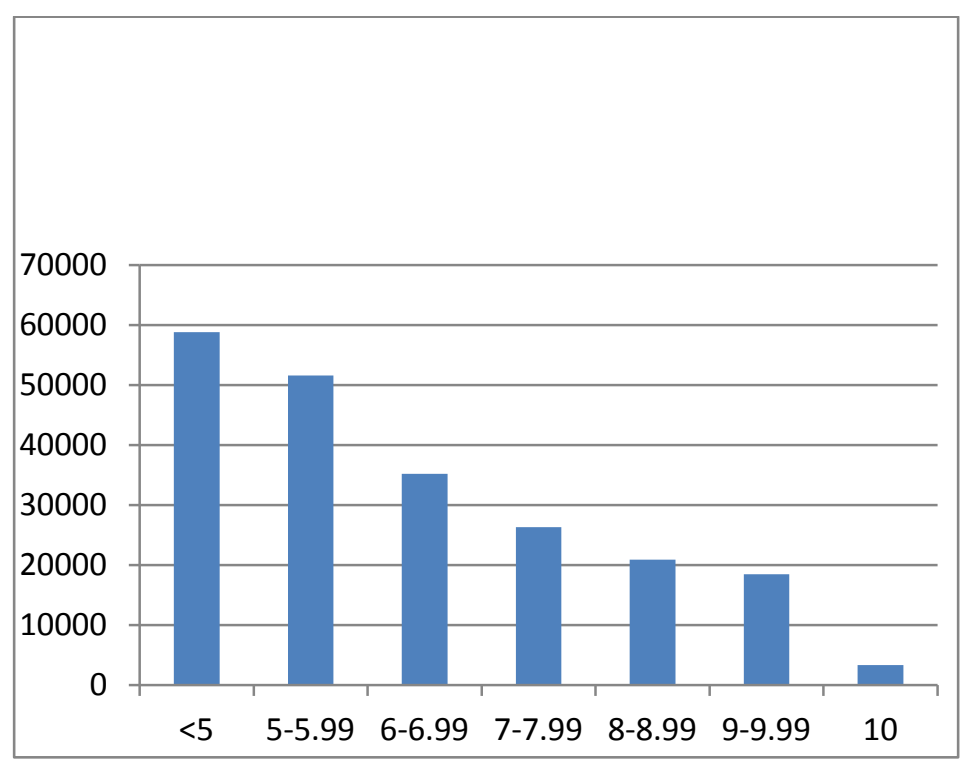


Table 3. Structure of the Education System

\begin{tabular}{|c|c|c|c|c|}
\hline Age & Grade & \multicolumn{3}{|c|}{ Education Levels } \\
\hline \multirow{3}{*}{$>19$} & & \multicolumn{2}{|c|}{ Post-Graduate Education } & Higher Education and \\
\hline & & \multicolumn{2}{|c|}{ Higher Education } & $\begin{array}{l}\text { Postgraduate } \\
\text { Education }\end{array}$ \\
\hline & & \multicolumn{2}{|c|}{ Post High School Education } & $\begin{array}{l}\text { Post-Secondary } \\
\text { Non-Tertiary } \\
\text { Education }\end{array}$ \\
\hline 18 & XIII & \multirow{3}{*}{ HS Upper Cycle } & \multirow{2}{*}{ HS Upper Cycle } & \multirow{3}{*}{$\begin{array}{l}\text { Upper Secondary } \\
\text { Education }\end{array}$} \\
\hline 17 & XII & & & \\
\hline 16 & $\mathrm{XI}$ & & Completion & \\
\hline 15 & $\mathrm{X}$ & \multirow{2}{*}{ HS Lower Cycle } & \multirow{2}{*}{$\begin{array}{c}\text { Arts and Trades } \\
\text { School }\end{array}$} & \multirow{6}{*}{$\begin{array}{l}\text { Lower Secondary } \\
\text { Education }\end{array}$} \\
\hline 14 & IX & & & \\
\hline 13 & VIII & \multirow{4}{*}{\multicolumn{2}{|c|}{ First Cycle of Lower Secondary Education }} & \\
\hline 12 & VII & & & \\
\hline 11 & VI & & & \\
\hline 10 & $\mathrm{~V}$ & & & \\
\hline 9 & IV & \multirow{4}{*}{\multicolumn{2}{|c|}{ Primary Education }} & \multirow{4}{*}{ Primary Education } \\
\hline 8 & III & & & \\
\hline 7 & II & & & \\
\hline 6 & I & & & \\
\hline 5 & Preparatory & \multirow{3}{*}{\multicolumn{2}{|c|}{ Pre-Primary Education }} & \multirow{3}{*}{ Pre-School Education } \\
\hline 4 & Middle & & & \\
\hline 3 & Beginner & & & \\
\hline
\end{tabular}

Legend: Totally white background

\section{COMPULSORY}


Table 4. A typical distribution of weekly number of hours per $1^{\text {st }}-8^{\text {th }}$ grades and subjects

\begin{tabular}{|c|c|c|c|c|c|c|c|c|}
\hline The curricular area / subject & $\mathbf{I}$ & II & III & IV & $\mathbf{V}$ & VI & VII & VIII \\
\hline 1. Language and communication & $7-9$ & $7-9$ & $7-9$ & $7-9$ & $9-10$ & $8-9$ & 8-9 & $9-10$ \\
\hline A. $\quad$ Romanian & $7-8$ & $7-8$ & $5-7$ & $5-7$ & 5 & 4 & 4 & 4 \\
\hline B. $\quad$ Modern Language 1 & - & - & $2-3$ & $2-3$ & $2-3$ & $2-3$ & $2-3$ & $2-3$ \\
\hline $\begin{array}{ll}\text { C. } & \text { Modern Language } 2\end{array}$ & - & - & - & - & 2 & 2 & 2 & 2 \\
\hline D. Latin & - & - & - & - & - & - & - & 1 \\
\hline E. $\quad$ Electives & $0-2$ & $0-2$ & $0-2$ & $0-2$ & 0-1 & $0-1$ & 0-1 & 0-1 \\
\hline 2. Mathematics and Natural Sci. & 3-4 & $3-4$ & $4-6$ & $4-6$ & $4-6$ & $6-8$ & $7-10$ & $7-10$ \\
\hline A. Mathematics & $3-4$ & $3-4$ & $3-4$ & $3-4$ & $3-4$ & 4 & 4 & 4 \\
\hline B. Natural Sciences & - & - & $1-2$ & $1-2$ & - & - & - & - \\
\hline C. $\quad$ Physics & - & - & - & - & - & $1-2$ & $1-2$ & $1-2$ \\
\hline D. Chemistry & & & & & - & - & $1-2$ & $1-2$ \\
\hline E. Biology & & & & & $1-2$ & $1-2$ & $1-2$ & $1-2$ \\
\hline 3. $\quad$ Man and Society & $1-2$ & $1-2$ & $2-3$ & $3-5$ & $3-5$ & $3-5$ & $4-6$ & 6-7 \\
\hline A. Civic Education & - & - & $1-2$ & $1-2$ & - & - & - & - \\
\hline B. Civic Culture & - & - & - & - & $0-1$ & $0-1$ & $1-2$ & $1-2$ \\
\hline C. History and Geography & - & - & - & - & $2-3$ & $2-3$ & $2-3$ & - \\
\hline D. Romanian History & - & - & - & $1-2$ & - & - & - & 2 \\
\hline E. Romania's geography & - & - & - & $1-2$ & - & - & - & 2 \\
\hline F. Religion & 1 & 1 & 1 & 1 & 1 & 1 & 1 & 1 \\
\hline G. $\quad$ Electives & $0-1$ & $0-1$ & $0-1$ & 0-1 & $0-1$ & $0-1$ & 0-1 & $0-1$ \\
\hline 4. $\quad$ Arts & $2-3$ & $2-3$ & $2-3$ & $2-3$ & $2-3$ & $2-3$ & $2-3$ & $1-2$ \\
\hline A. Plastic Education & $1-2$ & $1-2$ & $1-2$ & $1-2$ & $1-2$ & $1-2$ & $1-2$ & $1-2$ \\
\hline B. Musical Education & $1-2$ & $1-2$ & $1-2$ & $1-2$ & $1-2$ & $1-2$ & $1-2$ & $1-2$ \\
\hline C. $\quad$ Electives & 0-1 & $0-1$ & $0-1$ & $0-1$ & $0-1$ & $0-1$ & 0-1 & $0-1$ \\
\hline 5. Physical Education and Sport & $2-3$ & $2-3$ & $2-3$ & $2-3$ & $1-2$ & $1-2$ & $1-2$ & 1-2 \\
\hline A. Physical Education & $2-3$ & $2-3$ & $2-3$ & $2-3$ & $1-2$ & $1-2$ & $1-2$ & 1-2 \\
\hline B. $\quad$ Electives & $0-1$ & $0-1$ & $0-1$ & $0-1$ & $0-1$ & $0-1$ & 0-1 & $0-1$ \\
\hline 6. $\quad$ Technologies & $1-2$ & $1-2$ & $1-2$ & $1-2$ & $1-2$ & $1-2$ & $1-2$ & $1-2$ \\
\hline A. $\quad$ Practical Abilities & $1-2$ & $1-2$ & $1-2$ & $1-2$ & - & - & - & - \\
\hline B. $\quad$ Technological Education & - & - & - & - & $1-2$ & $1-2$ & $1-2$ & $1-2$ \\
\hline C. Electives & $0-1$ & $0-1$ & $0-1$ & $0-1$ & $0-1$ & $0-1$ & 0-1 & $0-1$ \\
\hline $\begin{array}{ll}\text { 7. } & \text { Counseling and Orientation }\end{array}$ & 0-1 & $0-1$ & $0-1$ & $0-1$ & $1-2$ & $1-2$ & $1-2$ & 1-2 \\
\hline $\begin{array}{ll}\text { A. } & \text { Counseling and } \\
& \text { Orientation }\end{array}$ & - & - & - & - & $1-2$ & $1-2$ & $1-2$ & 1-2 \\
\hline B. $\quad$ Electives & 0-1 & $0-1$ & $0-1$ & $0-1$ & $0-1$ & $0-1$ & $0-1$ & $0-1$ \\
\hline $\begin{array}{l}\text { Minimal Number of Classes per } \\
\text { Week }\end{array}$ & 18 & 18 & 20 & 21 & 23 & 24 & 27 & 28 \\
\hline $\begin{array}{l}\text { Maximal Number of Classes per } \\
\text { Week }\end{array}$ & 20 & 20 & 22 & 23 & 26 & 28 & 29 & 30 \\
\hline
\end{tabular}

